\title{
Electroacoustic properties of quartz minerals in a finely dispersed state
} Syktyvkar state University, Russia, author of 392 scientific papers.

LEONID N. KOTOV - Syktyvkar State University, Syktyvkar, Russia - kotovIn@mail.ru

ELENA L. KOTOVA - Saint-Petersburg Mining University, Russia - kotova_el@pers.spmi.ru

LUDMILA N. GÖMZE - IGREX Engineering Service Ltd, Hungary - igrex@freemail.hu

Érkezett: 2020. 06. 30. " Received: 30. 06. 2020. - https://doi.org/10.14382/epitoanyag-jsbcm.2020.30

\section{Abstract}

The authors described a new method for studying the electroacoustic properties of piezoelectric particles and substances in a finely dispersed state. They obtained the values of the quality factor and the amplitude of electro-elastic vibrations of piezoelectric quartz particles with an average size of 75 microns. To observe the high-frequency response, the generator excited quartz powders with a pulsed electric field with a frequency of $16.5 \mathrm{MHz}$. The characteristics and quality factor of electro-elastic vibrations of powder particles of the following types of quartz were determined: artificial, smoky, citrine, amethyst, re-crystallized, veined granular, veined poleshaped. The content of impurities in the minerals of quartz is given. The presence of aluminum ions $\mathrm{Al}^{3+}$ in quartz minerals also causes a strong increase in the quality factor of electro-elastic vibrations of piezoelectric particles, which may also be associated which may be associated with a change in the surface charge of quartz particles. The authors also carried out studies on the distribution of quality factor and response amplitudes electro-elastic vibrations over regions of a large citrine plate.

Keywords: electroacoustic properties, quality factor of electro-elastic vibrations, minerals of quartz, piezoelectric particles, powder

Kulcsszavak: elektroakusztikus tulajdonságok, az elektro-elasztikus rezgések minôségi tényezôje, kvarc ásványai, piezoelektromos részecskék, por

\section{Introduction}

Piezoelectric materials are important functional materials that can generate an electrical response when the deformation of a solid with time changes [1-3]. Among the many different types of piezoelectric materials, quartz crystals are one of the most widely used traditional piezoelectric materials [4]. Piezoelectric materials are essential parts of the electronics and electrical equipment used for consumer and industrial applications, such as ultrasonic piezoelectric transducers, resonators, sensors, actuators, transformers. The development and use of elements and devices of functional electronics is currently an important and rapidly developing field of technology [5-9]. A distinctive feature of functional electronics is the performance of operations on radio signals in the absence of traditional discrete elements: capacitors, resistances, transistors, etc. Radio signals are processed as a result of the interaction of electromagnetic radiation with the special physical properties of a solid medium, for example, the elastic properties in which this radiation propagates. Functional acoustoelectronics occupied a special place among these areas, which had already found wide practical application due to its great technical capabilities. Widely used elements of acoustoelectronics, such as resonators on surface acoustic waves in cell phones. In acoustoelectronics, the excitation of acoustic vibrations and waves is widely used when a solid is placed in a high-frequency electromagnetic field.

Measurement of acoustic parameters, such as piezoelectric constants, Q-factor of oscillations of a piezoelectric solids, signal saturation field amplitude have become the most sensitive methods, and sometimes the only possible methods for determining the nature of materials [10-12]. One of the most important properties of quartz crystals is the infinitesimal damping of elastic vibrations or the infinitely large Q-factor of vibrations. Therefore, most effective devices of functional acoustoelectronics are built using a wide class of single crystals with various physical properties. A wide variety of physical properties is provided by nature, which under natural conditions has created many different crystals that cannot yet be created artificially [13]. In research work [14] the mechanisms of enhancing the piezoelectric properties and increasing the quality factor of vibrations by introducing impurities during the growth of quartz minerals in natural conditions was examined. This paper presents the results of a study of the acoustoelectronic properties and the quality factor of electro-elastic vibrations of the quartz minerals in comparison with similar properties of artificial quartz grown by man.

\section{Experimental methods and technique}

The electroacoustic response (EAR) method can be a convenient method to study electrical and elastic properties of crystals in a finely dispersed state (particles and powders) $[10,12]$. EAR method consists in the formation of an electric signal after excitation of a set of crystalline piezoelectric particles (piezoelectric powder) by electric impulse. EAR method allows studying dynamic electrical and elastic characteristics of substance at large amplitudes of electric fields and elastic deformations, which are unattainable by other methods. This method is simpler than the well-known electroacoustic echo method, since it uses one radio frequency pulse 


\begin{tabular}{lccccccccccc} 
No. & Type of quartz & \multicolumn{9}{c}{ Content of impurity elements, $\mathbf{1 0}^{\mathbf{4}}$ wt \% } \\
& elements & $\mathrm{Al}$ & $\mathrm{Ti}$ & $\mathrm{K}$ & $\mathrm{Mg}$ & $\mathrm{Na}$ & $\mathrm{Fe}$ & $\mathrm{Li}$ & $\mathrm{Cu}$ & $\mathrm{Mn}$ \\
\hline $\mathbf{2}$ & Smoky & 32.4 & 17.1 & 18.8 & 3.8 & 3.9 & 5.4 & 0.6 & 0.6 & 0.2 \\
\hline $\mathbf{3}$ & citrine & 222 & 13.1 & 7.5 & 1.7 & 2.5 & no & 19.2 & 0.5 & 0.1 \\
\hline $\mathbf{4}$ & amethyst & 27.3 & 4.5 & 2.6 & 1.2 & 1.9 & no & 4.1 & 0.9 & 0.1 \\
\hline $\mathbf{5}$ & vein recrystallized & 51 & 16.3 & 4.5 & 4.7 & 9.9 & no & 4.5 & 0.5 & 0.2 \\
\hline $\mathbf{6}$ & vein granular & 384 & 24.2 & 27 & 25 & 21.5 & 19.5 & 0.08 & 1.3 & 0.5 \\
\hline $\mathbf{7}$ & vein columnar & 79 & 21.8 & 23.1 & 8.5 & 30 & 5.8 & 0.2 & 0.4 & 0.2
\end{tabular}

1. táblázat A kvarc ásványok szennyeződései

Table 1 Content of impurities in the minerals of quartz.

to excite powder particles $[10,12]$. A close two-pulse echo technique involves exposing the powder to two pulses. For the effective excitation of elastic vibrations of piezoelectric particles, it is necessary that the condition of acoustic resonance is satisfied, that is, when the particle sizes are of the order of the elastic wavelength. With its help, it is possible to study charges, defects, and their mobility in crystalline particles, which appear in large samples only in a weak form. The analysis of results of study of substance by EER method is possible only with a clear understanding of the mechanisms resulting in formation of a high-frequency response and time intervals of observing the electrical response. To clarify the differences in the electroelastic properties of various quartz minerals, piezoelectric powders made from artificial and quartz minerals $\left(\alpha-\mathrm{SiO}_{2}\right)$ with different content of impurities created under natural conditions were used.

The electro-elastic response can be observed in powders in time intervals during which sound attenuation in the crystal occurs [11]. This time for solids does not exceed a fraction of a second, therefore, the existing standard equipment for observing nuclear-quadrupole resonance (NQR) satisfies all the requirements imposed on the duration, amplitude of radio frequency pulses, and amplitude of weak receiving signals. In this work, all studies of the electroacoustic response of quartz powders on a pulsed panoramic spectrometer (ISP-1, USSR) were performed. The main blocks and elements are (Fig. 1): RF pulse generator, matching and measuring device in the form of LC circuit (inductance coil with capacitor), HF receiver of weak signals, an oscilloscope for observing signals. The spectrometer ISP-1 had the following characteristics: operating frequency range 1-20 MHz, duration of radio pulses 1-100 $\mu \mathrm{s}$, amplitude of voltage supplied to a capacitor with inductor $0.1-3 \mathrm{kV}$. Dead time interval is from the end of the exciting pulse at which it is impossible to observe the electro-elastic response, was $30 \mu$ s. All measurements were performed at room temperature. During the experiments amplitude of the electric response at a frequency $16.5 \mathrm{MHz}$ after time $\tau=30 \mu \mathrm{s}$ from an exciting radio frequency $(\mathrm{RF})$ pulse with a duration $\Delta \mathrm{t}=4 \mu \mathrm{s}$ were determined. The quality factor of electro-elastic vibrations of the particles of quartz powder $Q=N$, where $N$ is the number of vibrations for which the response amplitude decreases in $e$ times.

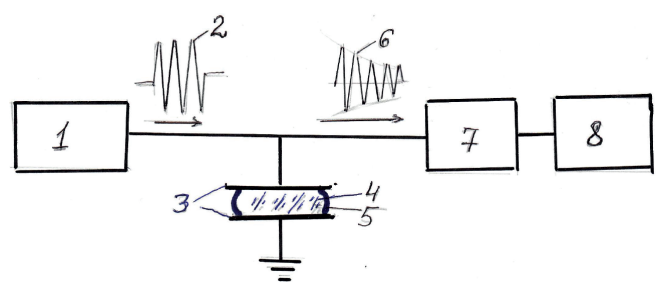

1. ábra A piezoelektromos porok elektro-elasztikus válaszának vizsgálatára szolgáló berendezés vázlata. Az ábrán látható: 1 - rádiófrekvencia-generátor, 2 rádiófrekvencia-impulzus, 3 - kondenzátorlemezek, 4 - kvarcpor, 5 - ampulla, 6 - elektromos válasz, 7 - rádiófrekvenciás vevö, 8-oszcilloszkóp

Fig. 1 The block diagram of the installation for the study of electro-elastic response from piezoelectric powders. The diagram shows: 1 - a radio frequency generator, 2 - a radio frequency pulse, 3 - capacitor plates, 4 - quartz powder 5 - an ampoule, 6 - electrical response, 7 - a radio frequency receiver, 8-oscilloscope.

\section{Preparation, characteristics and composition of samples}

The experiments on the study of quartz were performed on powder samples placed in glass ampoules with a diameter of $0.6 \mathrm{~cm}$ and a length of $2 \mathrm{~cm}$ [12]. The volume of quartz powder in all experiments was $0.3 \mathrm{~cm}^{3}$. After high-temperature heating at $700 \mathrm{~K}$ and pumping air from the ampoules to pressure $10^{2}$ $\mathrm{Pa}$, the ampoules were sealed. Vacuum of the powder was done in order to reduce the attenuation of the elastic vibrations of the powder particles by air molecules and to prevent the adsorption of air molecules, especially oxygen molecules and $\mathrm{OH}$ hydroxyl groups, on the surface of quartz particles [12]. For effective radio-frequency excitation and observation of the electro-elastic response of powder particles, it is necessary that the dimensions of the excited powder particles $l_{i}$ correspond to the condition of elastic resonance, and the length of the elastic half-wave in the test substance to be equal to, where - length, speed and frequency of an elastic wave [11]. Considering that in the experiments: $v=16.5 \mathrm{MHz}, \vartheta \approx 5.75 \cdot 10^{3} \mathrm{~m} \cdot \mathrm{s}^{-1}$, the particle size of all the studied quartz powders was $l_{\mathrm{i}} \approx(50 \div$ 100) $\mu \mathrm{m}$.

In the Subpolar Urals (Russia), a wide variety of vein quartz is widely developed, which is used as technical raw material. Table 1 shows average content of impurities of hydrothermal vein quartz of the Lyapinsky anticlinorium $[15,16]$. The content of impurities ( $\mathrm{Al}, \mathrm{Cu}, \mathrm{Fe}, \mathrm{Mg}, \mathrm{Mn}$ ) was determined by the spectral method at the Institute of Geology of the Komi Science Center of the Ural Branch of the Russian Academy of Sciences (Syktyvkar, Russia), Na, Ka, Li - at St. Petersburg Mining University (St. Petersburg, Russia). 


\begin{tabular}{lcccc} 
No. & Types of quartz & $\mathbf{Q} \cdot \mathbf{1 0}^{-3}$ & $\mathbf{E}_{\mathbf{0 1}}, \boldsymbol{\mu} \mathbf{V} / \mathbf{c m}$ & $\mathbf{E O} \mathbf{m a x}, \mathbf{k V} / \mathbf{c m}$ \\
\hline $\mathbf{1}$ & artificial & 9,2 & 120 & 0.7 \\
\hline $\mathbf{2}$ & smoky & 38,1 & 96 & 0.8 \\
\hline $\mathbf{3}$ & citrine & 43,1 & 66 & 0.7 \\
\hline $\mathbf{4}$ & amethyst & 11,6 & 40 & 0.8 \\
\hline $\mathbf{5}$ & vein recrystallized & 20,0 & 60 & 0.8 \\
\hline $\mathbf{6}$ & vein granular & 16,5 & 55 & 0.6 \\
\hline $\mathbf{7}$ & vein columnar & 7,1 & 53 & 0.6
\end{tabular}

2. táblázat A kvarcásványi porok elektroakusztikus reakcióinak jellemzői

Table 2 Characteristics of the electroacoustic responses of quartz mineral powders.

\section{Results and discussion}

In this paper for the first time is presented data on the study of the electroacoustic properties of various types of quartz minerals by the method (Table 2) $[17,18]$. The table shows the following values: $Q$ - quality factor of electro-elastic vibrations; $E_{01}$-response amplitudes after exposure to one pulse; $E_{0 \max }{ }^{-}$ the amplitude of the electric field at which the saturation of the amplitude of the elastic vibrations of the particles begins. Amplitudes $E_{01}$ were recorded on an oscilloscope at time $\tau=30 \mu$ s after the action of an pulse of duration $4 \mu \mathrm{s}$ with amplitude $\mathrm{E}_{0}=0.6 \mathrm{kV} / \mathrm{cm}$.

As can be seen from the table, the piezoelectric effect is most pronounced for artificial and smoky quartz (the response amplitude $E_{01}$ is proportional to the piezoelectric moduli). Amethyst quartz has the weakest high-frequency piezoelectric effect among minerals. The large value of $Q$ factor of electroelastic vibrations of powder particles is characteristic of citrine quartz, which is most likely due to the high content of aluminum impurities in it (Table 1), which results in decreasing sound attenuation, since $Q \sim \alpha^{-1}, \alpha$ - sound attenuation coefficient [11]. Small values of the quality factor $Q$ of oscillations correspond to artificial and columnar quartz. Small values may be associated with a low content of aluminum impurities.

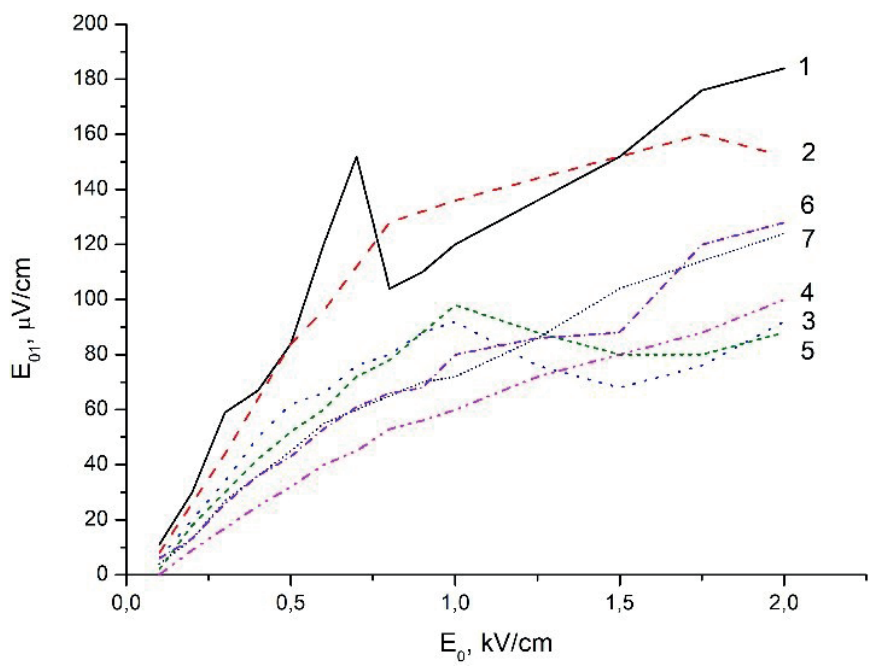

2. ábra A válasz amplitúdójának függése a kvarcok HF mezö amplitúdójától: mesterséges (1), füstös (2), citrin (3), ametiszt (4), erezetten átkristályosodott (5), erezett-szemcsézésü (6), oszlopos erezetü (7)

Fig. 2 Dependences of the response amplitude on the HF field amplitude for quartz types: artificial (1), smoky (2), citrine (3), amethyst (4), vein recrystallized (5), vein granular (6), vein columnar (7)
Dependences of the response amplitude on the field amplitude were divided into two areas (Fig. 2). For the first region at $E_{0}<E_{\text {omax }}$, linear increase in the response amplitude from the amplitude of the electric field is observed. The second region $E_{0}>E_{\text {omax }}$ corresponds to the saturation region of the elastic vibrations of the quartz powder particles. For most quartz, especially artificial quartz, the jumps in the response amplitude were observed in the saturation region. Perhaps this is due to the presence of HF breakdown in quartz particles.

Studies on the distribution of quality factor and response amplitudes electro-elastic vibrations over regions of a citrine polished plate with dimensions $275.122 \mathrm{~mm}^{2}$ and thickness $4 \mathrm{~mm}$ (Fig. 3) were also carried out. This plate is made of a large mineral. In the center of the citrine plate, the response amplitudes are $\mathrm{E}_{01}=90$, and at the edges less than $\mathrm{E}_{01} \approx 60$, which corresponds to the fact that the crystallinity at the center of quartz minerals is better than at the edges. The quality factor is $Q \approx 28 \cdot 10^{3}$ in the center of the citrine plate, and more than $Q=15 \cdot 10^{3}$ at the edges, which corresponds to the fact that the amount of impurities, especially $A l$, is much larger at the edges than in the center. The largest values of the amplitude of the electro-elastic response $E_{01}$ correspond to the two central cells of the mineral plate. It was hypothesized that the central regions of the mineral have a good degree of crystallinity.

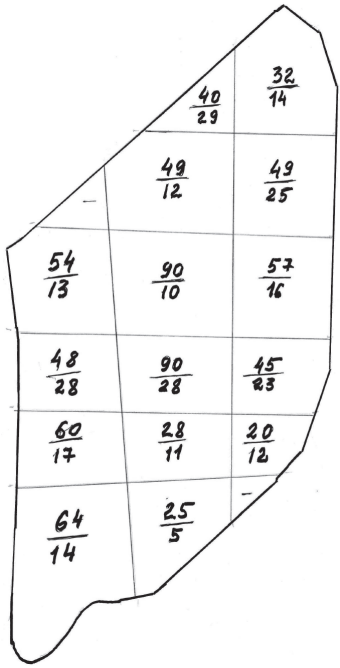

3. ábra Az E01 (a számlálóban) és a Q-tényezö (a nevezőben 10-3-kal szorozott) amplitúdójának eloszlása az elektro-elasztikus rezgésekkel a citrinlemez celláiban

Fig. 3 Distribution of response amplitudes $E_{01}$ (in the numerator) and Q-factor (multiplied by $10^{-3}$ in the denominator) electro-elastic vibrations in the cells of a citrine plate. 


\section{Conclusions}

A new method was described for studying the electroacoustic properties of piezoelectric particles and substances in a finely dispersed state. The values of the quality factor $Q$ and the amplitude of electro-elastic vibrations of quartz particles with an average size of 75 microns were obtained. Quartz minerals from the hydrothermal veins of the Lyapinsky anticlinorium (Subpolar Ural, Russia) were investigated. The content of impurities in the minerals of quartz is given. The characteristics and quality factor of electro-elastic vibrations of powder particles of the following types of quartz were determined: artificial, smoky, citrine, amethyst, re-crystallized, veined granular, veined pole-shaped. The results have shown that the qualitative factor of electro-elastic vibrations is determined by the state of the surface and the presence of water in quartz particles. For example, vacuum heat treatment (at $600 \mathrm{~K}$ ) of the surface of a quartz piezoelectric powder results in increasing quality factor of particle elastic oscillations by more than an order of magnitude. Such an increase in the quality factor of vibrations is associated with the physical and chemical desorption of molecules from the surface of piezoelectric particles during vacuum heat treatment. The breaking of bonds on the surface of quartz particles due to desorbed molecules increases the need for compensation of electric fields and results in the redistribution of charges in the particles. From this fact can be concluded that the presence of a surface charge on particles creates a state like a stretched string. The presence of aluminum ions $\mathrm{Al}^{+3}$ in quartz minerals also causes a strong increase in the quality factor of electro-elastic vibrations of piezoelectric particles, which may also be associated with this state. Studies on the distribution of quality factor and response amplitudes electro-elastic vibrations over regions of a citrine polished plate were also carried out.

\section{Acknowledgment}

The authors are deeply grateful to P.P. Yukhtanov, a researcher at the Institute of Geology of the Komi Science Center of the Ural Branch of the Russian Academy of Sciences (Syktyvkar, Russia) for providing quartz minerals and a useful discussion.

\section{References}

[1] Zhang, S. - Li, F. - Yu, F. - Jiang, X - Lee, H. Y. - Luo, J. -Shrout, T. R.: Recent Developments in Piezoelectric Crystals. Review. Journal of the Korean Ceramic Society, Vol. 55 No. 5 (2018) 419-439. p. https://doi.org/10.4191/kcers.2018.55.5.12

[2] Heywang, W. - Lubitz, K. - Wersing, W.: Piezoelectricity: Evolution and Future of a Technology. NY: Springer Science \& Business Media (2008)
[3] Li, F. - Cabral, M. J. - Xu, B. - Cheng, Z. X. - Dickey E. C. at al.: Recent developments in piezoelectric crystals. J. Korean Ceram. Soc., Vol. 55 (2018) 419-439. p.

[4] Mohammadi, M. M.: A comparison between quartz and PZT ceramic for Sensoric applications. Research Desk. Vol. 2 No. 4. (2015)

[5] Park, S. E. - Shrout, T.R.: Ultrahigh strain and piezoelectric behavior in relaxor based ferroelectric single crystals. J. Appl. Phys. Vol. 82 (1997) 1804-1811. p.

[6] Trolier-McKinstry, S. -Zhang, S. -Bell, A. J. - Tan. X.: High-Performance Piezoelectric Crystals, Ceramics, and Films. Annu. Rev. Mater. Res., Vol. 48 No. 1. (2018) 191-217.p.

[7] Iwazaki, Y. - Yokoyama, T. - Nishihara, T. - Ueda, M.: Highly enhanced piezoelectric property of co-doped AlN. Appl. Phys. Express, Vol. 8 (2015) 061501.

[8] Hackenberger -Bellaiche, L. -Xu, Z. -Chen, L. Q. -Shrout, T. R. -Zhang, S. J.: Giant piezoelectricity of Sm-doped $\mathrm{Pb}(\mathrm{Mg} 1 / 3 \mathrm{Nb} 2 / 3) \mathrm{O} 3-\mathrm{PbTiO} 3$ single crystals. Science, Vol. 364 (2019) 264-268. p.

[9] Moreira, M. - Bjurström, J. - Katardjev, I. - Yantchev, V.: Aluminum scandium nitride thin- film bulk acoustic resonators for wide band applications. Vacuum, Vol 86 (2011) 23-26. p.

[10] Kajimura, K.: Dynamic polarization echoes in powders materials. In: Phys. Acoust., N.Y., Vol. 16 (1982) 295-340. p.

[11] Ultrasound. Little Encyclopedia. Editor-in-chief Golyamina I.P. Soviet Encyclopedia. Moscow, (1979) 400 p.

[12] Shutilov, V. A. - Andzhikovich, I. E. - Komashnya, V. L. - Kotov, L. N.: Glass-like anomalies of electro-acoustic echo in crystalline quartz powders. Solid State Physics, Vol. 27 No. 3 (1985) 929-930. p.

[13] Kurovics, E. - Kotova, O. B. - Gömze, L. A .- Shushkov, D. A. - Ignatiev, G. V. - Sitnikov, P. A. - Ryabkov, Y. I. - Vaseneva, I. N. - Gömze, L. N.: Preparation of particle-reinforced mullite composite ceramic materials using kaolin and IG-017 bio-origin additives, Építőanyag - JSBCM, Vol. 71, No. 4 (2019), 114-119. p. https://doi.org/10.14382/epitoanyag-jsbcm.2019.20

[14] Kotova, O. B. - Harja, M. - Kotov L. N. - Ponaryadov, A. V.: Titanium minerals as prototypes of functional materials with pronounced electromagnetic properties // Vestnik of Institute of Geology of Komi SC of UB of RAS. No. 4. (2018) 34-39. p. (doi 10.19110/2221-1381-2018-434-39)

[15] Kuznetsov, S. K.: Vein quartz of the circumpolar Urals. St. Petersburg: Nauka, (1998) 204 p.

[16] Lyutoev, V. P.: Chalcedony structure and spectroscopy. UB RAS, Yekaterinburg, (2004) $116 \mathrm{p}$.

[17] Kotov, L. N. - Yukhtanov P.P.: Mechanisms of attenuation of electroacoustic echo. Collection of materials of the conference "Structure, substance, history of the lithosphere of Timan-Northern Ural segment". Syktyvkar, (1992) 62.

[18] Kotov, L. N. Electroacoustic echo in quartz powders. Theses of the AllUnion Conference "Mineralogy of quartz". Syktyvkar, (1992) 32.

$\underline{\text { Ref.: }}$

Kotov, Leonid N. - Kotova, Elena L. - Gömze, Ludmila N.: Electroacoustic properties of quartz minerals in a finely dispersed state

Építőanyag - Journal of Silicate Based and Composite Materials, Vol. 72, No. 5 (2020), 178-181. p. https://doi.org/10.14382/epitoanyag-jsbcm.2020.30 